\title{
ANALISIS KEMAMPUAN KOMUNIKASI MATEMATIS SISWA DENGAN GAYA BELAJAR KOMPETITIF
}

\author{
Heni Purwati ${ }^{1)}$, Dhian Endah Wuri ${ }^{2)}$ \\ 1) 2) FPMIPATI, Universitas PGRI Semarang \\ ${ }^{1)}$ honey_uga@yahoo.co.id \\ 2) endahwuri_dhian@yahoo.co.id
}

\begin{abstract}
The purpose of this study is to analyze the communication skills of students of SMP Eka Sakti Semarang who have a competitive learning style. The type of research is descriptive qualitative. Data collection techniques using test methods and interviews. The subjects consist of 2 grade VII students who have a competitive learning style. The data validity technique uses source triangulation. The results showed that both subjects showed the same mathematical communication ability indicators: 1) were less able to express mathematical ideas through oral, written, and demonstrated and visualized;2) able to understand, interpret and evaluate mathematical ideas either orally, or in visual form; and 3) able to use terms - mathematical notations through oral, written, and interpreting and visualizing. These results show that they understand the problems faced but are not accustomed to writing them coherently, this is due to the aggressiveness of students with competitive learning styles more motivate them to complete the job quickly and correctly rather than following the procedure.
\end{abstract}

Keywords: mathematical communication, learning style

\section{PENDAHULUAN}

Kemampuan mengkomunikan suatu ide, pikiran, ataupun pendapat sangatlah penting. Dalam lampiran Permendikbud Nomor 58 Tahun 2014 tentang Kurikulum SMP dijelaskan bahwa mata pelajaran matematika bertujuan agar siswa mampu mengkomunikasikan gagasan, penalaran serta mampu menyusun bukti matematika dengan menggunakan kalimat lengkap, simbol, tabel, diagram, atau media lain untuk memperjelas keadaan atau masalah. kemampuan matematis ialah kemampuan siswa dalam menjelaskan suatu algoritma dan cara unik untuk pemecahan masalah, kemampuan siswa mengkonstruksikan dan menjelaskan sajian fenomena dunia nyata secara grafis, kata-kata atau kalimat, persamaan, tabel, sajian secara visik atau kemampuan siswa memberikan dugaan tentang gambar-gambar geometri (NCTM, 2000). Selain itu Komunikasi adalah bagian esensial dari matematika dan pendidikan matematika. Komunikasi merupakan cara berbagi gagasan dan klarifikasi pemahaman (Wahyudin, 2012:527).

Indikator kemampuan Komunikasi matematis pada pembelajaran matematika menurut NCTM (1989: 214) dapat dilihat dari :
(1) Kemampuan mengekspresikan ide-ide matematika melalui lisan, tertulis, dan mendemonstrasikannya serta mengggambarkan-nya secara visual; (2) Kemampuan memahami, menginterpretasikan, dan mengevaluasi ide-ide Matematika baik secara lisan maupun dalam bentuk visual lainya; (3) Kemampuan dalam menggunakan istilah-istilah, notasi-notasi Matematika dan struktur-skrukturnya untuk menyajikan ide, menggambarkan hubungan-hubungan dan model-model situasi. Baroody (1993) mengemukakan terdapat lima aspek komunikasi, kelima aspek itu adalah: (a) Representasi, (b) Menyimak (listening), (c) Membaca (reading), (d) Diskusi (Discussing), (e) Menulis (writing). Nurahman (2011: 107) menyimpulkan bahwa komunikasi matematis itu terdiri dari komunikasi lisan dan tulisan.

Satu dari sekian banyak hal yang dapat berpengaruh terhadap kemampuan siswa ialah gaya belajar. Gaya belajar terdiri dari dua pandangan utama, gaya belajar yang melalui proses informasi individu (audiotory, visual, dan kinestetik), dan yang melalui hubungan individu dengan pembelajar lain (kolaboratif dan kolaboratif) (Burguillo, 2010). 
Gunawan (2006) mendefinisikan gaya belajar sebagai cara yang lebih disukai dalam melakukan kegiatan berfikir, memproses dan mengerti suatu informasi. Sedangkan Ma (2014) yang mendefinisikan gaya belajar sebagai cara yang mana seseorang mulai berkosentrasi pada proses, internal, dan mengingat dan informasi akademik yang baru dan sulit. Dalam seting kelas, pelajar bersaing melaksanakan rencana pembelajaran individualistik dan menerapkan strategi pembelajaran yang memungkinkan pelajar mencapai tujuan pembelajaran. Pelajar yang mempunyai daya saing (kompetitif) menginginkan untuk tidak hanya menjadi yang pertama dalam mencapai keberhasilan sebagai tujuan tetapi juga mencapai tujuan untuk lebih terkenal dari teman sebaya. Keuntungan utama dari gaya belajar kompetitif adalah motivasi yang merangsang upaya pembelajaran (Burguillo, 2010). Anderson \& Morrow (1995) menemukan adanya perbedaan antara metode kooperatif dan kompetitif dalam meningkatkan agresivitas, perintah yang bernuansa kompetitif lebih meningkatkan agresivitas pada anak.

\section{METODE PENELITIAN}

Penelitian ini bertujuan untuk menggali kemampuan komunikasi matematis siswa kelas VII SMP Eka Sakti Semarang pada pemecahan masalah yang berkaitan dengan materi pecahan. Hasil tersebut akan dideskripsikan secara kualitatif. Penggalian data dilakukan secara mendalam melalui wawancara atas jawaban soal tes yang diberikan terlebih dahulu. Oleh karena itu, penelitian ini didesain dengan jenis penelitian eksprolatif dengan pendekatan deskriptif kualitatif. Subjek penelitian diperoleh menggunakan criterion-based selection (Muhajir, 2002) yaitu pemilihan subjek yang memenuhi kriteria yang ditetapkan. Subjek diperoleh dengan penggolongan gaya belajar melalui angket, kemudian dilakukan observasi untuk mendapatkan subyek yang representatif. Subjek yang digunakan ialah 2 siswa kelas VII dengan gaya belajar kompetitif. Teknik pengumpulan data menggunakan metode tes dan wawancara. Sedangkan teknik analisis data menggunakan metode deskriptif. Adapun teknik keabsahan data menggunakan triangulasi sumber, yaitu dengan membandingkan data yang diperoleh dari beberapa sumber untuk malihat kekonsistensian data.

\section{HASIL DAN PEMBAHASAN}

1. Subjek MRA

a. Hasil kerja MRA

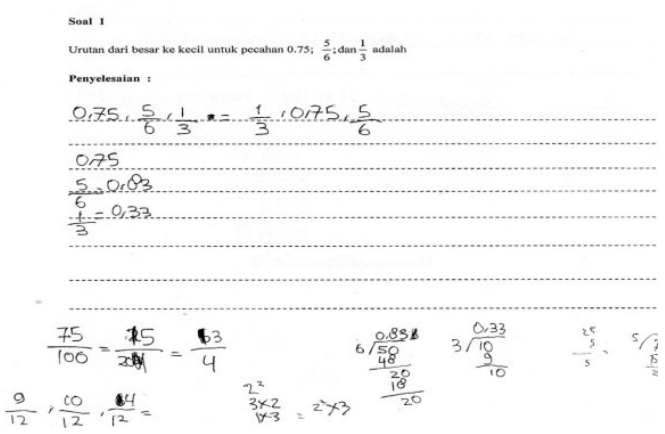

Gambar 1. Pekerjaan MRA no 1

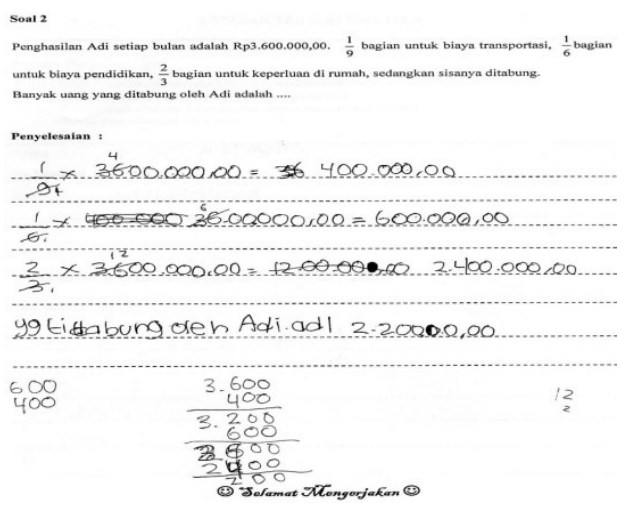

Gambar 2. Pekerjaan MRA no 2

Dari pekerjaan MRA yang no 1 dan 2,

Berdasarkan pekerjaan MRA nomor 1, dapat dilihat bahwa MRA kurang dapat memahami maksud dari soal/ permasalahan yang diberikan. MRA belum mengekspresikan ide -ide matematika dalam menuliskan jawaban, MRA sudah menuliskan notasi-notasi matematika tetapi belum menjelaskan maksud dari apa yang sudah ditulisnya. MRA sudah menginterpretasikan notasi tersebut dalam bentuk lain (dalam hal ini MRA mengubah bentuk pecahan biasa ke bentuk decimal).

Untuk pekerjaan Nomor 2, MRA juga belum memberikan keterangan apapun pada jawabannya, selain itu MRA juga tidak memperhatikan penulisan symbol yang benar, (dalam hal ini pada penulisan bilangan jutaan, dan ratusan ribu, dia tidak memperhatikan 
peletakkan titik sehingga bilnangan tersebut menjadi bermakna). MRA sudah membuat kesimpulan dari penyelesaian permasalahannya walaupun belum benar.

Berdasarkan keterangan no 1 dan 2 tersebut menunjukkan bahwa MRA hanya menuliskan angka-angka yang ada di soal tanpa memberikan keterangan apapun pada pekerjaannya, MRA tidak mencermati kalimat yang menyertainya, sehingga menyebabkan salah dalam pengambilan keputusan.

b. Hasil wawancara

Jika dilihat berdasarkan kemampuan komunikasi matematisnya, maka pekerjaan MRA bisa diuraikan sebagai berikut:

$\mathrm{T}$ : Ini yang diketahui apa dari soalnya?

$\mathrm{J}$ : Desimal

$\mathrm{T}$ : Hanya decimal? Yakin?

$\mathrm{J}$ : Pecahan biasa

$\mathrm{T}$ : apa saja pecahannya?

$\mathrm{J}$ : nol koma tujuh lima, lima per enam, satu per tiga

$\mathrm{T}$ : Itu soalnya diminta untuk apa?

$\mathrm{J}$ : mengurutkan daari besar ke kecil

Berdasarkan wawancara di atas, dapat disimpulkan bahwa MRA belum mampu mengekspresikan ide ide matematika secara lisan dari soal yang sebenarnya sederhana, MRA mengatakan bingung ketika ditanya tentang soalnya, kemudian juga ketika ditanya tentang bentuk pecahan yang ada di soal, dia menjawab dengan tidak tuntas. Untuk memahami dan menjelaskan apa yang diketahui dari soal tersebut MRA memerlukan pertanyaan pancingan

$\mathrm{T}$ : Bagaimana cara mengurutkannya?

$\mathrm{J} \quad$ : diubah ke bentuk decimal dulu

$\mathrm{T}$ : Bisa dijeelaskan?

$\mathrm{J} \quad$ : 6 dibagi 5 ?

$\mathrm{T}$ : eh, 6 dibagi 5

$\mathrm{J}$ : terbalik

$\mathrm{T}$ : yang terbalik menulisnya atau membacanya?

$\mathrm{J}$ : membacanya

5 dibagi 6 tidak bisa ditambahi 0 , yang atas nol koma, trus 6 dikali berapa yang mendekati 50, 6 dikali $8=48$, trus itu dikurangi. $50-48=20$

Eh 2, 2 tidak bisa dibagi 6 ditambahi 0 , trus 6 dikali berapa yang hasilnya 20, 3 dan seterusnya.

T : 3 nya berhenti disini atau masih terus?

$\mathrm{J} \quad$ : masih terus
$\mathrm{T} \quad$ : terus yang $\frac{1}{3}$ sama?

$\mathrm{J} \quad$ : iya

Berdasarkan jawaban MRA, dia bisa memahami bagaimana menyelesaikan permasalahan dan mendemonstrasikannya. Dia bisa menceritakan alur bagaimana mengubah bentuk pecahan biasa ke bentuk desimal. Hanya saja dalam menyampaikan secara lisan kurang teliti (5 per 6 , artinya 6 dibagi 5 dan 50 dikurangi $48=20$ ). Hal ini menujukkaan MRA belum bisa menggunakan istilah- istilah atau symbol-simbol dalam bentuk lisan.

$\mathrm{T}$ : Menurutmu, ada cara lain untuk menjawab soal itu?

Ini ada pecahan biasa dan pecahan decimal, boleh tidak kalau diubah ke pecahan biasa? Kemudian dibandingkan

$\mathrm{J} \quad$ : bisa

$\mathrm{T}$ : coba 0,75 diubah ke pecahan biasa!

J $: \frac{75}{100}$

MRA sudah bisa menginterpretasikan ideide matematika yaitu mengubah suatu pecahan decimal ke pecahan biasa dengan cepat. Ini berarti MRA memahami konsep pecahan decimal.

c. Kesimpulan kemampuan komunikasi matematis MRA

1) Mengekspresikan ide-ide matematika melalui lisan, tertulis, dan mendemonstrasi-kan serta menggambarkan secara visual

Berdasarkan analisis pekerjaan dan hasil wawancara, MRA masih belum bisa mengekspresikan ide-ide yang terdapat dalam soal baik secara lisan maupun tulisan, bahkan mengetahui pertanyaannya sekalipun. MRA kurang teliti dalam memecahkan masalah. MRA bisa mendemonstrasikan langkah langkah menghitung tetapi masih memerlukan bimbingan secara bertahap.

2) Memahami, menginterpretasikan dan mengevaluasi ide-ide matematika baik secara lisan, maupun dalam bentuk visual Berdasarkan jawaban dan wawancara, MRA belum sepenuhnya memahami ideide matematikanya, untuk menginterpretasikan jawaban dia butuh bimbingan bertahap dan untuk mengevalusi pada hitungan langsung MRA tidak terlalu membutuhkan bantuan, 
hanya masih perlu dibimbing tapi untuk soal dengan bentuk cerita yang lebih panjang dia memerlukan bantuan ilustrasi yang lebih sederhana, baru dia bisa menyimpulkan kasus yang sebenarnya sedang dia hadapi

3) Menggunakan istilah -istilah, notasi-notasi matematika melalui lisan, tulisan, dan menginterpretasikan serta menggambarkan secara visual

MRA hanya menuliskan angka-angka saja pada jawaban yang dituliskan di kertas, tanpa memberikan keterangan. Hal ini juga menunjukkan bahwwa MRA kurang cermat dalam mengerjakan soal. MRA paham cara menghitung dengan berbagai metode dengan menggunakan istilahistilah matematika, tetapi kurang teliti atau bahkan kurang memahami penerapan dari apa yang ia tulis dan ceritakan.

2. Subjek AAW
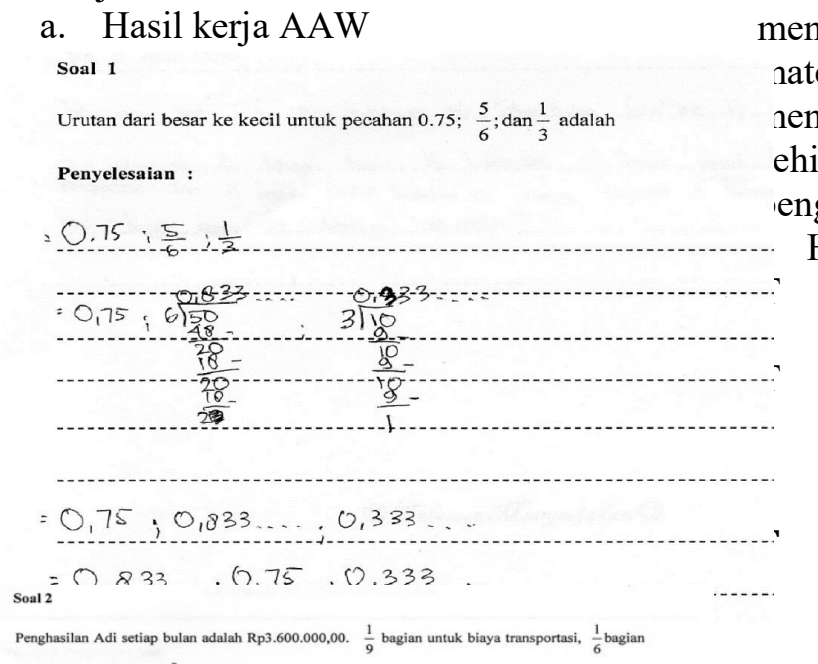

detail dalam menuliskan jawaban, AAW sudah menuliskan notasi-notasi matematika serta mampu mengekspresikan apa yang seharusnya dikerjakan (dalam hal ini AAW mengubah bentuk pecahan biasa ke bentuk decimal). Dia menuliskan secara urut hasil perhitungannya dibawah bentuk pecahan yang ditanyakan secara runtut disertai dengan langkah penyelesaiannya, walaupun tidak diserti keterangan tambahan berupa kata-kata, tetapi sudah bias dipahami alur berpikirnya. Hal ini menunjukkan bahwa AAW sudah bisa memahami cara penyelesaian masalahnya.

Untuk pekerjaan Nomor 2, AAW sudah memahami apa yang sebenarnya harus dilakukan. AAW Menuliskan symbol-simbol perkaliannya dengan rinci. AAW tidak menyertakan keterangan pendamping dalam menyelesaikan masalahnya, sehingga mungkin hal itu yang membuat dia agak bingung dalam penyelesaian akhir dan membuat kesimpulan

Berdasarkan keterangan no 1 dan 2 tersebut menunjukkan bahwa AAW sudah bias mengerjakan secara runtut dengan ide-ide aatematika yang benar, AAW belum aencermati inti kalimat pertanyaannya, ehingga menyebabkan salah dalam engambilan keputusan.

Hasil wawancara dengan AAW

: menyelesaikannya bagaimana?

: mengubah ke decimal dulu

: bisa diceritakan?

: pakai pembagian

$\frac{5}{6}, 6$ dibagi 5

$: \frac{5}{6}$, artinya 5 dibagi 6 atau 6 dibagi 5 ?

: 5 dibagi 6

(sambil menjelaskan tulisan perhitungan pembagian menggunakan porogapit). 5 dibagi 6 ndak bisa ditambah nol, dikasih koma terus 50 dibagi $6,8.8$ dikali 6,48 . 50 dikurangi 48, 2. Ditambah nol, 20 dibagi 6, 3. 3 dikali 6, 18. 18 dibagi 6, 3 . Dan seterusnya

$\mathrm{T}$ : jawabannya bagaimana?

J $: \frac{5}{6}, 0,75, \frac{1}{3}$

$\mathrm{T} \quad$ : Kok bisa mengurutkan seperti itu?

$\mathrm{J} \quad$ : dilihat 0,$833 ; 0,7 ; 0,33$

dapat dilihat bahwa AAW sudah dapat memahami maksud dari soal/ permasalahan yang diberikan. AAW sudah bisa mengekspresikan ide -ide matematika secara
$\mathrm{T}$ : dilihatnya dari mana?

J : 0,$8 ; 0,7 ; 0,33$

Dilihat dari angka dibelakang koma 
Dari jawaban yang dikemukakan oleh AAW terlihat bahwa AAW dapat memahami ide-ide matematis baik secara lisan maupun tulisan, serta telah mampu mendemonstrasikan penyelesaian dengan langkah-langkah yang benar. AWW juga bias menginterpretasikan jawabannya dengan rinci dan benar. Hal ini bias terlihat dari pekerjaannya dalam mengbah bentuk pecahan biasa ke pecahan decimal. Dan AWW juga bisa menjelaskan dengan istilahistilah dan simbol-simbol matematis. Hanya saja AWW beberapa kali terbalik dalam memmbaca operasi hitungan, meskipun mengerjakannya sudah benar.

$\mathrm{T}$ : Untuk no 2, apa yang diketahui?

J : yang diketahui $\frac{1}{9}, \frac{1}{6}, \frac{2}{3}$ ditambah

$\mathrm{T}: 3.600 .000$ apa?

$\mathrm{J}: 3.600 .000$ penghasilan tiap bulan

$\mathrm{T}$ : yang ditanyakan apa?

$\mathrm{J} \quad$ : uang yang ditabung Adi

Dari percakapan diatas, terlihat bahwa AAW dapat memahami apa yang diketahui dan ditanyakan dalam soal cerita yang diberikan. Walau dalam menceritakan tidak secara langsung, tetapi bertahap.

$\mathrm{T}$ : Cara mengerjakannya bagaimana?

J $: \frac{1}{9}+\frac{1}{6}+\frac{2}{3}$

Penyebutnya belum sama, disamakan dulu. Caranya menggunakan KPK

$$
\begin{aligned}
& 18: 9=2,2 \times 1=2 \\
& 18: 6=3,3 \times 1=3 \\
& 18: 3=6,6 \times 2=12 \\
& \text { Ditambah } 17 \\
& \text { Jadi } \frac{17}{18} \times 3.600 .000 \\
& =17 \times 200.000 \\
& =3.400 .000
\end{aligned}
$$

Penjelasan diatas, menunjukkan AAW dapat memahami dan menjelaskan langkah langkah penyelesaian cecara rinci.

c. Kesimpulan kemampuan komunikasi matematis AAW

1) Mengekspresikan ide-ide matematika melalui lisan, tertulis, dan mendemonstrasi-kan serta menggambarkan secara visual.

Berdasarkan analisis pekerjaan dan hasil wawancara, AAW sudah bisa mengekspresikan ide-ide yang terdapat dalam soal baik secara lisan maupun tulisan. AAW mampu menjelaskan tahapan-tahapan dalam penyelsaian masalah dengan memberikan keterangan tambahan yang dibutuhkan.

2) Menggunakan istilah -istilah, notasi-notasi matematika melalui lisan, tulisan, dan menginterpretasikan serta menggambarkan secara visual.

AAW menuliskan angka-angka saja pada jawaban yang dituliskan di kertas dengan runtut, walaupun tidak dibeikan keterangan tambahan berupa kata-kata pendukung. Tapi pekerjaannya cukup bisa dipahami. Hal ini juga menunjukkan bahwwa AAW cermat dalam mengerjakan soal. AAW paham cara menghitung dengan berbagai metode dengan menggunakan istilah-istilah matematika, tetapi kurang teliti dalam membaca operasi matematika dengan benar dari pekerjaan yang telah dituliskan

3) Memahami, menginterpretasikan dan mengevaluasi ide-ide matematika baik secara lisan, maupun dalam bentuk visual. Berdasarkan jawaban dan wawancara, AAW sudah memahami ide-ide matematikanya, dan telah mampu menginterpretasikan jawaban dalam bentuk yang lain. Untuk mengevalusi jawaban akhir, AAW kurang cermat dalam memahami masalah, AWW masih perlu dibimbing terutama untuk soal dengan bentuk cerita AAW perlu pancingan berulang-ulang, baru dia bisa menyimpulkan kasus yang sebenarnya sedang dia hadapi

3. Hasil Triangulasi data Subjek MRA dan AAW

Berdasarkan data yang diperoleh Subjek MRA dan AAW, maka diperoleh data yang sama yaitu:

1) kurang mampu mengekspresikan ide-ide matematika melalui lisan, tertulis, dan mendemonstrasi-kan serta menggambarkan secara visual.

2) mampu memahami, menginterpretasikan dan mengevaluasi ide-ide matematika baik secara lisan, maupun dalam bentuk visual; dan

3) mampu menggunakan istilah -istilah, notasi-notasi matematika melalui lisan, tulisan, dan menginterpretasikan serta menggambarkan secara visual.

Hasil ini menunjukan bahwa mereka memahami permasalahan yang dihadapi tetapi 
tidak terbiasa menuliskannya secara runtut, hal ini disebabkan oleh agresifitas yang dimiliki siswa dengan gaya belajar kompetitif lebih memotivasi mereka menyelesaikan pekerjaan dengan cepat dan benar dari pada mengikuti prosedur. Burguillo (2010) menyebutkan bahwa pelajar yang mempunyai daya saing (kompetitif) menginginkan untuk tidak hanya menjadi yang pertama dalam mencapai keberhasilan sebagai tujuan tetapi juga mencapai tujuan untuk lebih terkenal dari teman sebaya. Hal ini sejalan dengan hasil penelitian Anderson \& Morrow (1995) yang menemukan adanya perbedaan antara metode kooperatif dan kompetitif dalam meningkatkan agresivitas, perintah yang bernuansa kompetitif lebih meningkatkan agresivitas pada anak. Penelitian ini sejalan dengan hasil penelitian yang dilakukan Nizaruddin., Dwijayanti., \& Harun (2013) yang menghasilkan simpulan bahwa komunikasi yang dilakukan siswa selama pembelajaran mempunyai hubungan yang linier dengan kebiasaan siswa dalam belajar yang berwujud pada karakter siswa. Selain itu penelitian ini juga mendukung hasil penelitian Purwati \& Nugroho (2017) yang menyatakan bahwa beberapa faktor yang mempengaruhi siswa dalam mengkomunikasikan gagasan dalam memecahkan masalah salah satunya ialah ialah kebiasaan siswa.

\section{KESIMPULAN}

Berdasarkan hasil penelitian yang telah diuraikan maka diperoleh kesimpulan bahwa analisis kemampuan komunikasi matematis siswa ditinjau dari gaya belajar melalui metaanalisis diperoleh hasil bahwa kedua subjek menunjukkan indikator kemampuan komunikasi matematis yang sama yaitu:

a. kurang mampu mengekspresikan ide-ide matematika melalui lisan, tertulis, dan mendemonstrasi-kan serta menggambarkan secara visual;

b. mampu memahami, menginterpretasikan dan mengevaluasi ide-ide matematika baik secara lisan, maupun dalam bentuk visual; dan

c. mampu menggunakan istilah -istilah, notasi-notasi matematika melalui lisan, tulisan, dan menginterpretasikan serta menggambarkan secara visual.

\section{REFERENSI}

Anderson, C.A., \& Morrow, M. (1995). Competitive aggression without interaction: Effects of competitive versus cooperative instructions on aggressive behavior in video games. Personality and Social Psychology Bulletin. Vol 21: 1020-1030.

Baroody, A.J. 1993. Problem Solving, Reasoning, and Communicating, $K-8$. Helping Children think Mathematically. New York: Macmillan Publishing Company.

Burguillo, JC. 2010. Using game theory and competition-based learning to stimulate student motivation and performance. Computers and Education. Vol 55, 566575.

Gunawan, A. W. (2006). "Genius Learning Strategi”. Jakarta: Pustaka Utama

Ma, X, Jong, C, \& Yuan, J. 2013. Exploring reasons for the East Asian success in PISA. In H Meyer \& A Benavot (Eds.), PISA, power, and policy: the emergence of global educational governance ( $p p$. 225-246). Oxford, United Kingdom: Symposium Books.

Muhajir, Noeng. Penelitian Kualitatif, Yogyakarta: Rake Salasin, 2002.

National Council of Teacher of Mathematics (NCTM). 2000. Principles and Standards for School Mathematics. Reason. VA:NTCM.

National Council of Teachers of Mathematics (NCTM). 1989. Assesment Standar for School Mathematics. USA: The National Council of Teachers of Mathematics, Inc.

Nizaruddin,. Dwijayanti, I., Harun, L. 2013. Efektivitas Komunikasi Masa Terhadap Karakter Mahasiswa Matakuliah Metodologi Penelitian Pendidikan. AKSIOMA. Vol 4 (1): 1-11.

Nurahman, I. 2011. Pembelajaran Kooperatif Tipe Team-Accelerated Instruction (TAI) untuk Meningkatkan Kemampuan Penalaran dan Komunikasi Matematis 
Siswa SMP. Pasundan Journal of Mathematics Education. Tahun 1, Vol. 1, 96-130

Peraturan Menteri Pendidikan Dan Kebudayaan Nomor 54 Tahun 2013 (2013). Standar Kompetensi Lulusan Pendidikan Dasar Dan Menengah, Jakarta.

'Purwati, H \& A A, Nugroho. 2017. Analisis Kemampuan Komunikasi Matematis Mahasiswa Dalam Menyelesaikan Masalah Pada Mata Kuliah Program Linear. Jurnal Ilmiah Pendidikan Matematika. Vol 1(2): 127 - 134.

Wahyudin. 2012. Filsafat dan Model-Model Pembelajaran Matematika. Bandung: Mandiri. 